\title{
Response of surf zone fish to beach nourishment operations on the northern coast of New Jersey, USA
}

\author{
D. H. Wilber ${ }^{1, *}$, D. G. Clarke ${ }^{2}$, G. L. Ray ${ }^{2}$, M. Burlas ${ }^{3}$ \\ ${ }^{1}$ Dyn Corps, 664 Old Plantation Road, Charleston, South Carolina 29412, USA \\ ${ }^{2}$ US Army Engineer Research and Development Center, Wetlands and Coastal Ecology Branch, 3909 Halls Ferry Road, \\ Vicksburg, Mississippi 39180-6199, USA \\ ${ }^{3}$ US Army Engineer District, 26 Federal Plaza, New York, New York 10278, USA
}

\begin{abstract}
Surf zone fishes were captured by beach seine over the late summer and early fall of $5 \mathrm{yr}$ (1995 to 1999), spanning pre-, during, and post-nourishment time periods along a $15 \mathrm{~km}$ expanse of the New Jersey shoreline. During the baseline years of sampling, silversides (primarily Menidia menidia) numerically dominated the surf-zone fish community. In 1997, coincident with beach nourishment operations, bluefish Pomatomus saltatrix became numerically dominant, increasing in abundance 10-fold. Bluefish were not captured near active beach nourishment sites and were significantly more abundant at reference stations than in the beach nourishment (treatment) area for 2 of 6 sampling dates in 1997. In contrast, northern kingfish Menticirrhus saxatilis were more abundant at treatment stations in 1997, and on one occasion congregated at the stations undergoing active sand replenishment. The feeding habits of Atlantic silversides and northern kingfish were consistent throughout the study period. In 1997, prey biomass was greater in fish caught at treatment stations when significant differences occurred. Prey consisted primarily of benthic invertebrates such as polychaetes and mole crabs. Amphipods and insects, which probably originated from groins and terrestrial sources respectively, were also common prey items and were present in plankton samples. Retrospective power analysis indicates that an approximate 3-fold difference in mean fish abundance was the minimum detectable effect size between reference and treatment areas. Beach nourishment impacts on the surf zone fish monitored in this study were restricted to localized attraction (northern kingfish) and avoidance (bluefish) responses to the beach nourishment operation.
\end{abstract}

KEY WORDS: Beach seine $\cdot$ Dredging $\cdot$ Filling $\cdot$ Bluefish $\cdot$ Kingfish $\cdot$ Silversides $\cdot$ Power analysis · Turbidity $\cdot$ Fish food habits

\section{INTRODUCTION}

In contrast to the well-recognized importance of enclosed estuarine systems as nursery habitat for the larvae and juveniles of many marine fish species, less is known about the functional role of surf zone habitat for juvenile fish (Lenanton et al. 1982, Ruple 1984, Lasiak 1986, Bennett 1989, Beyst et al. 2001). Surf zone habitats have been viewed as harsh environments that are difficult to effectively sample (Schaefer 1967, Lasiak 1984), which may account for the relative lack of information regarding the dependence of young fish on this habitat type. The importance of surf zone habitat as a nursery area for juvenile fish along the high-energy beaches of the eastern United States and northern Gulf of Mexico is becoming increasingly evident (Ross et al. 1987, Lazzari et al. 1999, Layman 2000, Able et al. in press). Increases in coastal development and erosion control measures, along with a greater emphasis on defining and protecting critical fish habitats, have all contributed to a growing interest in how beach restoration projects affect surf-zone fish communities. In this study, we examine the potential impacts of a beach nourishment project along a portion of the northern New Jersey shoreline on the feeding habits and distribution and abundance patterns of surf zone fish. 
Hard structures, such as seawalls, bulkheads, and groins, are effective in stabilizing uplands and protecting existing structures, but do not prevent the erosion of adjoining beaches, which narrow and may eventually disappear (Pilkey \& Wright 1988). Hard stabilization measures, therefore, have been increasingly replaced by beach nourishment operations, which replace sediments lost through natural or humaninduced erosion with sand removed from a borrow (dredging) site. Repeated nourishment is often necessary to keep pace with erosion. For example, $88 \%$ of nourished beaches along the Atlantic coast require replenishment within $5 \mathrm{yr}$ of the initial nourishment (Leonard et al. 1990). More frequent beach nourishment and nourishment of more beaches may be expected under a scenario of increasing rates of sea level rise (Peterson et al. 2000).

Beach nourishment may affect surf zone finfish through reductions in benthic prey and shelter availability and the disruption of fish distribution patterns. The placement of sand on the beach buries, at least temporarily, existing benthic habitat, which may reduce the availability of infauna to benthic feeders. In cases where sediment texture is substantially changed due to the placement of a higher fraction of fine sediments on the beach, recovery of benthic infaunal communities may be delayed (Reilly \& Bellis 1983, Peterson et al. 2000). Where there is a high correspondence between the fill site and ambient beach sediments (e.g. Nelson 1993, Van Dolah et al. 1994, Hackney et al. 1996, Jutte et al. 1999, Burlas et al. 2001), infaunal recolonization is more rapid and potential limitations to benthic food availability are reduced. Another potential effect arises when hard-substrate habitats, such as groins, are partially or totally buried by sediments, which may reduce the value of these structures as foraging and shelter sites. Additionally, the physical disturbance caused by dredging and the pumping of sand onto the beach may affect fish distribution patterns. High suspended sediment concentrations can negatively affect the physiology and feeding behavior of visually orienting estuarine fish (reviewed in LaSalle et al. 1991, Wilber \& Clarke 2001). In the majority of cases studied in the SE United States (Nelson 1993), known effects of beach nourishment are limited to short-term reductions in infaunal biomass (an indicator of secondary production) and impacts to higher surf zone trophic levels have been inferred. Few studies that examine the biological impacts of beach nourishment projects are published in peer-reviewed journals, thus predictions of potential impacts on surf zone fishes, especially along the NE coast of the United States, are made with considerable uncertainty.

In this study, we examine the distribution, abundance, and taxonomic richness of surf zone fishes captured by beach seine in northern New Jersey over the late summer and early fall of 5 yr (1995 to 1999) in adjoining areas of beach - a reference area and an area nourished over the summer and early fall of 1997. A descriptive account of the surf zone fish assemblage

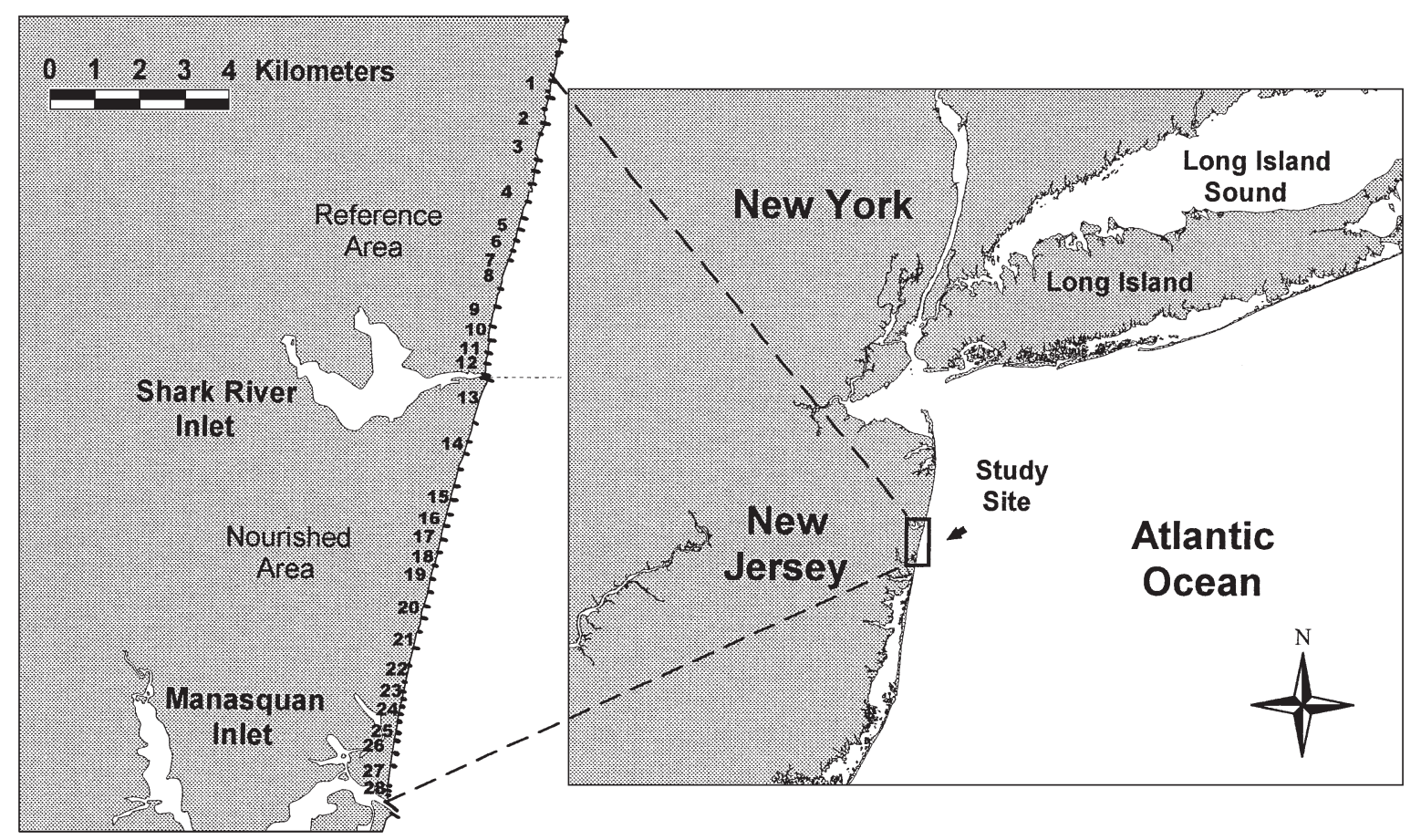

Fig. 1. Location of study site spanning approximately $15 \mathrm{~km}$ along the northern New Jersey shoreline 
(Wilber et al. 2003) includes a full species list and size frequency and recruitment information, but does not address potential impacts of the beach nourishment project. Briefly summarized, nearly 300000 fish were captured over the $5 \mathrm{yr}$ duration of the study, representing 57 species from 30 families. Over $90 \%$ of the surfzone fish catch each year was comprised of 5 or fewer species, and typically included Atlantic and rough silversides, Menidia menidia and Membras martinica respectively, bluefish Pomatomus saltatrix, and bay and striped anchovies Anchoa mitchilli and A. hepsetus. The relative abundances of these taxa varied among years, with as much as a 10-fold change in abundance for some species. To determine whether the beach nourishment project affected surf zone fish, we compared fish abundances and food habits between reference and beach nourishment (treatment) areas before, during, and after the beach nourishment operation. We used retrospective power analysis to examine the efficacy of using an extensive survey-style sampling protocol to detect potential impacts to surf zone fish.

\section{MATERIALS AND METHODS}

Beach seine sampling. In 1997, approximately 3.6 million $\mathrm{m}^{3}$ of sand were placed along $9.6 \mathrm{~km}$ of beach between the Shark River and Manasquan Inlets in northern New Jersey (Fig. 1), yielding a $30 \mathrm{~m}$ wide berm to an elevation of $3 \mathrm{~m}$ above mean low water. The surf zone habitat along this stretch of beach (hereafter referred to as the treatment area) and along an adjacent $5.4 \mathrm{~km}$ section of unnourished beach (reference area) was sampled biweekly from 1995 to 1999 by beach seine between late summer (usually August) and mid-October (Table 1), which coincides with the autumnal occurrences of some transient species (Schaefer 1967, Briggs 1975, McDermott 1983). Sampling time periods are defined as pre-nourishment (or baseline - 1995 and 1996), during nourishment (1997), and post-nourishment (1998 and 1999).

Sampling was conducted at low tide during daylight, with 6 sampling dates in 1995 to 1997, 5 in 1998 and 4 in 1999 (Table 1). Severe weather conditions accounted for the missed sampling dates. Sampling was curtailed for safety reasons when wave heights exceeded ca. $1.5 \mathrm{~m}$. Fishes were collected at 28 stations separated by groins of similar quarry rock construction that were located approximately $0.8 \mathrm{~km}$ apart (Fig. 1). The beach seine measured $15.2 \times 1.8 \mathrm{~m}$, with a $1.8 \times$ $1.8 \times 1.8 \mathrm{~m}$ bag and a $6 \mathrm{~mm}$ square mesh net. The seine was pulled perpendicular to the shoreline starting at a depth of approximately $1.25 \mathrm{~m}$. Stations were numbered consecutively from north to south, with Stns 1 to 12 in the reference area and Stns 13 to 28 in the treatment area (Fig. 1). The Shark River inlet separates Stns 12 and 13 and the Manasquan inlet borders the study area on the southern end of Stn 28. Three substations were sampled at every station: $\mathrm{A}$, on the southern side of the north groin; $B$, midway between the groins; and $\mathrm{C}$, on the northern side of the south groin. Therefore, 84 seine hauls were taken during a complete sampling date. The near-groin substations (A and C) were typically sampled to within several meters of the rock groins, which were partially buried by the nourishment project. Turbidity measurements (nephelometer turbidity units: NTU) were collected by a HydroLab ${ }^{\circledR}$ water quality meter that was deployed approximately $100 \mathrm{~m}$ offshore between the rock groins of each station at a depth of $1 \mathrm{~m}$; it was redeployed as each station was sampled.

Nourishment of the study area occurred from August to early October 1997 with active sand placement occasionally occurring during the time of sampling. The placement of sand on the beach near the sampling stations did not follow a simple temporal or spatial sequence, but can best be summarized as 10 of 16 stations (Stns 13 to 18 and 24 to 27 ) receiving some nourishment by the first sampling date, and an additional 4 stations (Stns 19 to 21 and 28) receiving nourishment by the third sampling date of 1997. Beach nourishment of all stations was completed by the fifth sampling date in 1997, and some stations received sand on several occasions throughout the operation.

All fishes were identified to the lowest practical taxonomic level and counted, although total numbers

Table 1. Sampling dates for the collection of surf zone finfish during the pre-nourishment (1995 and 1996), during nourishment (1997), and post-nourishment (1998 and 1999) time periods

\begin{tabular}{|c|c|c|c|c|c|}
\hline Sampling date & 1995 & 1996 & 1997 & 1998 & 1999 \\
\hline 1 & Jul 24-28 & Aug 12-17 & Aug 4-7 & Aug 3-7 & Aug 9-12 \\
\hline 2 & Aug 23-26 & Aug 26-29 & Aug 19-23 & Aug 17-21 & Aug 23-25 \\
\hline 3 & Sep 5-8 & Sep 9-12 & Sep 2-4 & - & - \\
\hline 4 & Sep 18-22 & Sep 23-27 & Sep 15-17 & Sep 14-17 & - \\
\hline 5 & Oct $2-6$ & Oct $7-12$ & Sep 30-Oct 3 & Sep 28-Oct 1 & Oct $4-8$ \\
\hline 6 & Oct $20-25$ & Oct $26-27$ & Oct $14,15,28,29$ & Oct $15-17$ & Oct $17-23$ \\
\hline
\end{tabular}


were estimated when extremely large numbers of fishes were caught (for example, schools of several thousand fish). Because it was impractical to sort large mixed catches of Atlantic and rough silversides in the field, their abundances were recorded as a pooled group and denoted as silversides. Subsamples of silversides were identified to the species level in the laboratory for stomach content analysis. These analyses revealed that Atlantic silversides comprised 65, 83, 94, and $96 \%$ of the silverside subsamples from 1996 to 1999 respectively (Burlas et al. 2001). Catches of bay and striped anchovies also were not segregated in the field from 1997 to 1999 and are treated as 1 taxon (Anchoa spp.), for the purposes of analyzing distribution and abundance patterns. Anchovies were identified to species level in 1995 and were comprised almost entirely (99\% of total anchovy catch) of striped anchovies, whereas the 1996 anchovy catch was comprised primarily of bay anchovies (76\%), most of which (>6000 fish) were captured in a single haul. Because fish were identified to the species level in most cases, taxonomic richness is analyzed and depicted as species number. The taxonomic groupings of 'silversides' and 'anchovies' are each treated as single species; therefore, the total number of species is a conservative estimate. Standard length (SL), measured from the end of the snout to the base of the caudal peduncle, was recorded for the first 100 haphazardly selected fish from each taxonomic group, except bluefish, where total length (TL) was recorded.

Food habits. Northern kingfish, and Atlantic and rough silversides were subsampled and fixed in 10\% formalin. Specimens were sorted into distinct size classes. Individual fish within each size class were dissected in the laboratory, and the stomach contents were removed. Stomach contents of fish captured at each substation on a single sampling date were pooled by species and size class as described by Borgeson (1963) and Sheridan (1979), sorted, and major taxonomic categories wet-weighed to yield a composite characterization of the diets of size classes of each predator species. This method sacrifices information on variation in diets of individual fish, but allows an accurate characterization of foraging habits at the population level. After the prey biomass was determined, the prey taxa were identified to the lowest practical taxonomic level. Data collected during the pre- (1996) and post- (1998 and 1999) nourishment years are summarized to provide background information on the extent of interannual variation in the fish diets. More detailed analyses by species and sampling date are presented for 1997, when beach nourishment occurred. To determine the potential effects of beach nourishment on fish feeding habits, we examined total prey biomass per non-empty stomach and the per- centage of non-empty stomachs for all fish dissected. Comparisons of prey types were calculated as prey biomass per non-empty stomach with the assumption of equivalent regurgitation across treatments. A concurrent monitoring study of beach benthos demonstrated that infaunal species composition, density, and biomass were similar between the reference and treatment areas during baseline years of sampling, suggesting that the forage base for benthic feeding fish was relatively homogeneous throughout the study area (Burlas et al. 2001). Rhynchocoels, oligochaetes, mole crabs Emerita talpoida and the polychaete Scolelepis squamata dominated the intertidal benthic infauna in this area and consistently comprised over $95 \%$ of all individuals and total benthic biomass across all years (Burlas et al. 2001). The occurrence of potential fish prey in plankton tows taken in the summer of each year, and qualitative scrapings of rock groins are noted.

Statistical methods. MANOVAs were calculated for each year of sampling using beach treatment area (reference vs treatment), groin proximity (near-groin vs mid-groin substation) and sampling date as independent factors, and abundances of numerically dominant species and all other fish combined ('rest of fish') as dependent variables. Separate 3-factor MANOVAs were conducted for 1995 to 1997. Insufficient sample sizes during some sampling dates prevented analysis by the full 3-factor design for the latter 2 years, therefore 2-factor (groin and treatment) MANOVAs were conducted for 1998 and 1999. Fish abundance data were $\left(\log _{10}[n+1]\right)$-transformed. Univariate ANOVAs were conducted for all significant MANOVA results, and Tukey's honestly significant difference (HSD) test was used to identify significantly different means (Wilkinson 1990). Species number was analyzed separately for each year by 3-factor ANOVAs using beach treatment area, groin, and date as independent variables. Power analyses were conducted using PASS software (Hintze 2000).

Food-habit data were analyzed using ANOVA models to test for differences in prey biomass for each prey type between fish caught at the reference and treatment stations. All statistical tests were performed on log-transformed prey biomass per non-empty stomach data for samples in which at least 5 fish of the same species with non-empty stomachs were captured. Other factors, such as fish size and substation groin proximity, were also used as independent variables as data permitted. Data were first pooled across size classes when sample sizes were limited because the relationship between food habits and fish size was not a focus of this study once it was established that the fish did not segregate by size between the reference and treatment areas (Wilber et al. 2003). 


\section{RESULTS}

\section{Fish distribution and abundance}

Baseline sampling

During the baseline years (1995 and 1996), silversides numerically dominated the beach seine catches in both the reference and treatment areas (Fig. 2). Fish abundance was relatively homogeneous between the reference and treatment areas in 1995 (Table 2), with the exception of silversides captured in higher abundances in the reference area during the fifth sampling date (Tukey HSD, $\mathrm{p}=0.011$ ), and 'rest of fish' captured in higher numbers at the groin substations in the treatment area during the second sampling date (Tukey HSD, $\mathrm{p}=0.005$ ). Significantly more silversides were captured near the groin substations than at the mid-groin substations in 1995 (Table 2). The mean abundances of fish at groin and mid-groin substations are depicted as total fish abundance for each year, rather than by individual fish species (Fig. 3), to simplify data presentation across years.

In 1996, fish abundances differed between the reference and treatment areas for one sampling date (Table 3). Silversides (Tukey HSD, p < 0.001), and 'rest of fish' (Tukey HSD, $\mathrm{p}=0.003$ ) were more abundant in the reference area on the third sampling date. Fish abundances were also greater at the near-groin substations for some sampling dates in 1996. Bluefish captures were higher at the groin substations during the first sampling date (Tukey HSD, p <0.001), whereas silversides were more abundant at the groin substations during the second (Tukey HSD, p <0.001) and fourth (Tukey HSD, $p=0.03$ ) sampling dates.

\section{During beach nourishment sampling}

Fish were less evenly distributed throughout the study area in 1997 compared to the baseline years of sampling. The significant interactions between treatment area and groin proximity for bluefish, silversides, and 'rest of fish' (Table 4) results from more fish being captured at the groin substations only in the reference area (Fig. 4, Tukey HSD, all p-values < 0.001). Bluefish were more abundant at the reference stations during the third (Tukey HSD, p = 0.001) and fourth (Tukey HSD, $\mathrm{p}<0.001$ ) sampling dates, whereas northern kingfish were more abundant in the treatment area during the first (Tukey HSD, p < 0.001), third (Tukey HSD, $\mathrm{p}<0.05)$, and fifth (Tukey HSD, $\mathrm{p}<0.05)$ sam-

Table 2. Results of MANOVA tests of whether fish abundance in 1995 differed between beach area (treatment, Trt), proximity of substation to groin habitat (Groin), and sampling date (Date). Results of subsequently conducted univariate 3-way ANOVAs are also shown for each response variable. Bold = significant results of interest

\begin{tabular}{|c|c|c|c|c|c|c|c|c|c|c|}
\hline \multirow[t]{2}{*}{1995} & \multicolumn{3}{|c|}{ MANOVA } & \multicolumn{4}{|c|}{ Silversides } & \multicolumn{3}{|c|}{ Rest of fish } \\
\hline & Wilk's $\lambda$ & $F$ & $\mathrm{p}$ & $\mathrm{df}$ & MS & $F$ & $\mathrm{p}$ & MS & $F$ & $\mathrm{p}$ \\
\hline Date & 0.57 & 30.45 & $<0.001$ & 5 & 151.49 & 63.57 & $<0.001$ & 0.39 & 3.18 & 0.008 \\
\hline Groin & 0.94 & 14.40 & $<0.001$ & 1 & 43.48 & 18.24 & $<0.001$ & 1.99 & 16.22 & $<0.001$ \\
\hline Treatment & .99 & 0.04 & 0.96 & 1 & 0.18 & 0.07 & 0.78 & 0.01 & 0.01 & 0.99 \\
\hline Date $\times$ Groin & 0.98 & 0.83 & 0.60 & 5 & 2.53 & 1.06 & 0.38 & 0.09 & 0.73 & 0.60 \\
\hline Date $\times$ Trt & 0.94 & 3.13 & 0.001 & 5 & 6.05 & 2.54 & 0.03 & 0.41 & 3.32 & 0.006 \\
\hline Groin $\times$ Trt & 0.99 & 0.31 & 0.73 & 1 & 0.38 & 0.16 & 0.69 & 0.07 & 0.56 & 0.45 \\
\hline Date $\times$ Groin $\times$ Trt & 0.97 & 1.32 & 0.21 & 5 & 1.39 & 0.58 & 0.71 & 0.29 & 2.35 & 0.04 \\
\hline Error & & & & 474 & 2.38 & & & 0.12 & & \\
\hline
\end{tabular}




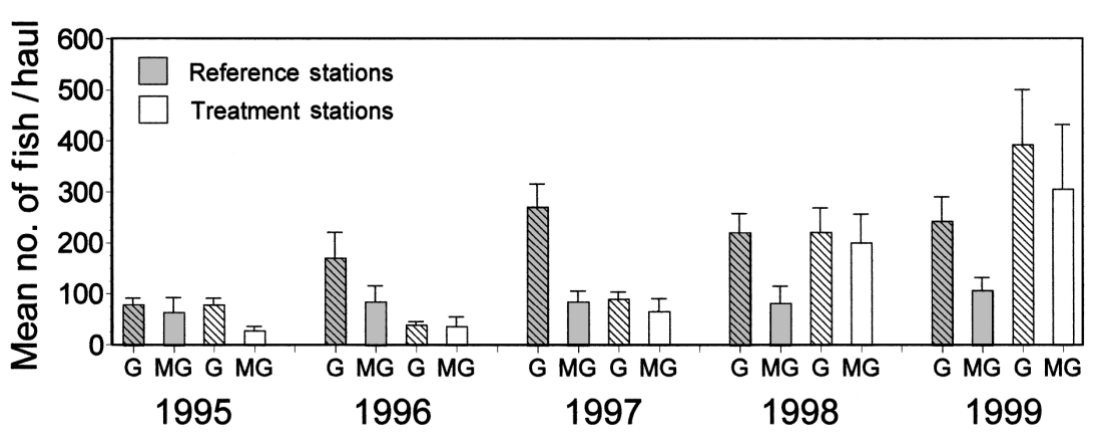

Fig. 3. Mean number of fish $( \pm$ SE) captured per haul at groin $(G$, hatched bars) and mid-groin ( $\mathrm{MG}$, no hatching) substations at reference (shaded bars) and treatment (open bars) stations for each year of sampling

pling dates (Fig. 5) and at groin substations throughout the study area (Table 4). For these species, fish distributions appeared to be directly related to the beach nourishment activities in 1997. Approximately $70 \%$ of the kingfish captured during the first sampling date (August 4 to 7) were captured in front of the active fill area (Fig. 6). In contrast, bluefish were typically not captured near an active beach fill area (for example, September 15 to 17, Fig. 7). In 1997, groin habitat was increasingly covered by sand from the nourishment activities with each successive sampling date; however, differences in total fish abundance and species richness between near-groin and mid-groin substations did not exhibit a temporal pattern over the 6 sampling dates (Fig. 8).

\section{Post-nourishment sampling}

There were differences in the distributions of several species between the reference and treatment areas of the beach in 1998 (Table 5). Silversides were captured in greater numbers at the groin substations only in the reference area during 1998 (Table 5, Tukey HSD, p = 0.002). Bluefish were more abundant in the reference area and 'rest of fish' were more abundant in the treatment area. Anchovy catches were highly skewed for all years, with most hauls capturing no anchovies, whereas a few hauls captured several thousand fish. Thus, the relatively high contributions of anchovies to

Table 3. Results of MANOVA tests of whether fish abundance in 1996 differed between beach area (treatment, Trt), proximity of substation to groin habitat (Groin), and sampling date (Date). Results of subsequently conducted univariate 3-way ANOVAs are also shown for each response variable. Bold = significant results of interest

\begin{tabular}{|c|c|c|c|c|c|c|c|c|c|c|c|c|c|}
\hline \multirow[t]{2}{*}{1996} & \multicolumn{3}{|c|}{ MANOVA } & \multicolumn{4}{|c|}{ Silversides } & \multicolumn{3}{|c|}{ Bluefish } & \multicolumn{3}{|c|}{ Rest of fish } \\
\hline & Wilk's $\lambda$ & $F$ & $\mathrm{p}$ & df & MS & $F$ & $\mathrm{p}$ & MS & $F$ & $\mathrm{p}$ & MS & $F$ & $\mathrm{p}$ \\
\hline Date & 0.69 & 11.73 & $<0.001$ & 5 & 9.77 & 19.20 & $<0.001$ & 2.91 & 11.29 & $<0.001$ & 3.48 & 13.20 & $<0.001$ \\
\hline Groin & 0.91 & 15.36 & $<0.001$ & 1 & 9.98 & 19.61 & $<0.001$ & 5.66 & 21.98 & $<0.001$ & 4.87 & 18.48 & $<0.001$ \\
\hline Treatment (Trt) & 0.97 & 4.56 & 0.004 & 1 & 5.12 & 10.05 & 0.002 & 0.20 & 0.77 & 0.38 & 1.25 & 4.75 & 0.03 \\
\hline Date $\times$ Groin & 0.87 & 4.13 & $<0.001$ & 5 & 4.99 & 9.80 & $<0.001$ & 0.97 & 3.76 & 0.002 & 0.15 & 0.56 & 0.74 \\
\hline Date $\times \operatorname{Trt}$ & 0.90 & 3.28 & $<0.001$ & 5 & 3.47 & 6.82 & $<0.001$ & 0.05 & 0.19 & 0.96 & 0.95 & 3.60 & 0.003 \\
\hline Groin $\times$ Trt & 0.99 & 0.97 & 0.41 & 1 & 0.62 & 1.22 & 0.27 & 0.06 & 0.21 & 0.65 & 0.51 & 1.92 & 0.17 \\
\hline Date $\times$ Groin $\times$ Trt & 0.99 & 0.45 & 0.96 & 5 & 0.56 & 1.11 & 0.36 & 0.01 & 0.03 & 0.99 & 0.07 & 0.25 & 0.94 \\
\hline Error & & & & 451 & 0.51 & & & 0.26 & & & 0.26 & & \\
\hline
\end{tabular}

Table 4. Results of MANOVA tests of whether fish abundance in 1997 differed between beach area (treatment, Trt), proximity of substation to groin habitat (Groin), and sampling date (Date). Results of subsequently conducted univariate 3-way ANOVAs are also shown for each response variable. Bold = significant results of interest

\begin{tabular}{|c|c|c|c|c|c|c|c|c|c|c|c|c|c|c|c|c|}
\hline \multirow[t]{2}{*}{1997} & \multicolumn{3}{|c|}{ MANOVA } & \multicolumn{4}{|c|}{ Bluefish } & \multicolumn{3}{|c|}{ Northern kingfish } & \multicolumn{3}{|c|}{ Silversides } & \multicolumn{3}{|c|}{ Rest of fish } \\
\hline & Wilk's $\lambda$ & $\lambda \quad F$ & $\mathrm{p}$ & $\mathrm{df}$ & MS & $F$ & $\mathrm{p}$ & MS & $F$ & $\mathrm{p}$ & MS & $F$ & $\mathrm{p}$ & MS & $F$ & $\mathrm{p}$ \\
\hline Date & 0.76 & 5.72 & $<0.001$ & 5 & 9.34 & 13.81 & $<0.001$ & 1.32 & 5.72 & $<0.001$ & 2.38 & 4.61 & $<0.001$ & 1.09 & 0.31 & 0.004 \\
\hline Groin & 0.881 & 16.12 & $<0.001$ & 1 & 10.99 & 16.26 & $<0.001$ & 1.47 & 6.40 & 0.01 & 18.79 & 36.39 & $<0.001$ & 5.75 & 18.40 & $<0.001$ \\
\hline Treatment (Trt) & 0.881 & 18.01 & $<0.001$ & 1 & 15.84 & 23.43 & $<0.001$ & 7.183 & $31.15<$ & $<0.001$ & 2.22 & 4.30 & 0.04 & 0.66 & 2.10 & 0.15 \\
\hline Date $\times$ Groin & 0.96 & 1.09 & 0.35 & 5 & 1.30 & 1.92 & 0.09 & 0.04 & 0.18 & 0.97 & 0.89 & 1.72 & 0.13 & 0.12 & 0.40 & 0.85 \\
\hline Date $\times$ Trt & 0.94 & 1.61 & 0.04 & 5 & 1.96 & 2.90 & 0.01 & 0.48 & 2.10 & 0.06 & 0.39 & 0.75 & 0.58 & 0.09 & 0.29 & 0.92 \\
\hline Groin $\times$ Trt & 0.96 & 4.47 & 0.001 & 1 & 4.32 & 6.39 & 0.01 & 0.14 & 0.62 & 0.43 & 3.72 & 7.20 & 0.008 & 1.41 & 4.51 & 0.03 \\
\hline Date $\times$ Groin $\times$ Trt & it 0.98 & 0.52 & 0.96 & 5 & 0.32 & 0.48 & 0.79 & 0.07 & 0.32 & 0.90 & 0.14 & 0.28 & 0.93 & 0.28 & 0.89 & 0.49 \\
\hline Error & & & & 473 & 0.68 & & & 0.23 & & & 0.52 & & & 0.32 & & \\
\hline
\end{tabular}


the total annual catch (for example, reference area 1996 and treatment area 1998 and 1999, Fig. 2) reflect occasional large hauls, rather than consistently high anchovy abundances in either area. In 1999, silversides were more abundant in the treatment area and bluefish were more abundant at the groin substations throughout the study area (Table 5).

\section{Taxonomic richness}

The number of species captured per haul ranged from 0 to 14 , with most hauls containing 2 to 3 species. There were significant interactions between beach area (reference vs treatment) and groin proximity variables in $1997(F=$ 8.23, $\mathrm{p}=0.004)$ and $1998(F=11.17, \mathrm{p}=0.001)$. In 1997, species number was greater at the groin substations in both the reference and treatment areas; however, the difference was more pronounced in the reference (Tukey HSD, p < 0.001) than the treatment (Tukey HSD, p = 0.008) area (Fig. 9). In 1998, species number at the groin substations in the reference area was greater than at mid-groin substations, whereas there was no difference in species number associated with groin proximity in the treatment area (Tukey HSD, $\mathrm{p}<0.001$, Fig. 9). In 1995, 1996, and 1999, species number did not differ between the treatment and reference areas, but was higher at the groin substations throughout the study area (Fig. 9). Species number differed significantly among sampling dates for all years (all p-values < 0.001), but there was no consistent trend in this variation among years (Wilber et al. 2003).

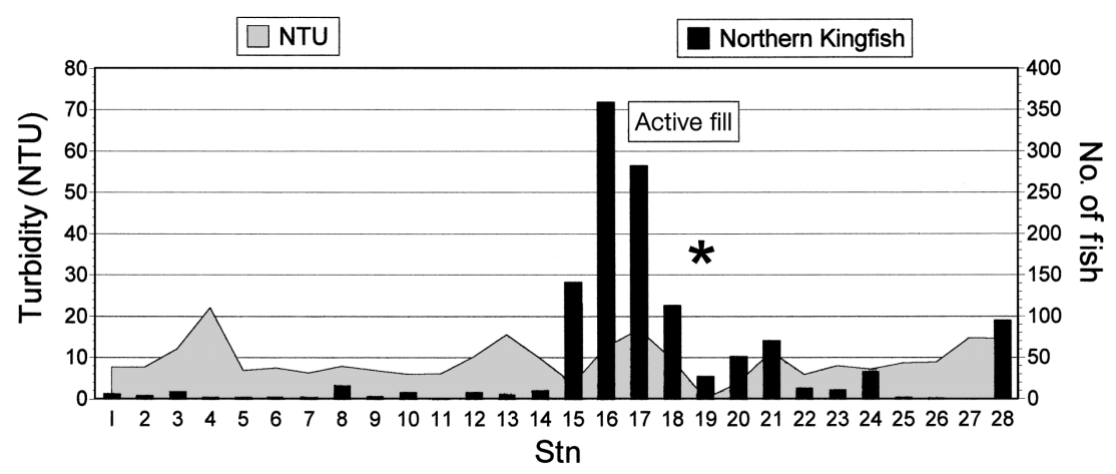

Fig. 6. Menticirrhus saxatilis. Total abundance of northern kingfish during the August 4 to 7, 1997 sampling date (black bars) and average turbidity (nephelometer turbidity units, NTU; shaded area) at each station. Asterisk denotes that no turbidity data were obtained near the active fill site, which was near Stn 18 at the time of sampling
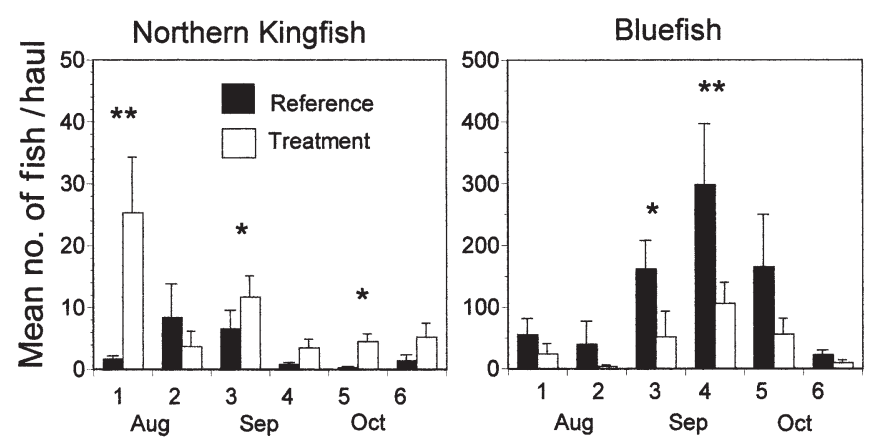

Fig. 5. Mean number $( \pm \mathrm{SE})$ of northern kingfish Menticirrhus saxatilis and bluefish Pomatomus saltatrix captured per haul during each sampling date of 1997. Asterisks above the histogram bars indicate the sampling dates with statistically significant differences $\left({ }^{*} \mathrm{p}<0.01,{ }^{* *} \mathrm{p}<0.001\right)$

\section{Food habits}

Atlantic silversides

Prior to nourishment, the identifiable portion of Atlantic silversides' prey biomass was dominated by amphipods, with lesser contributions by copepods and annelids (Fig. 10). Jassa falcata was the most abundant amphipod identified, and Hyale plumulosa was also present in both size classes of Atlantic silversides (Table 6). The polychaete Scolelepis squamata comprised the annelid biomass for large ( $\geq 60 \mathrm{~mm})$ silversides. Juvenile mole crabs were a numerous prey item, but did not account for much prey biomass in 1996 


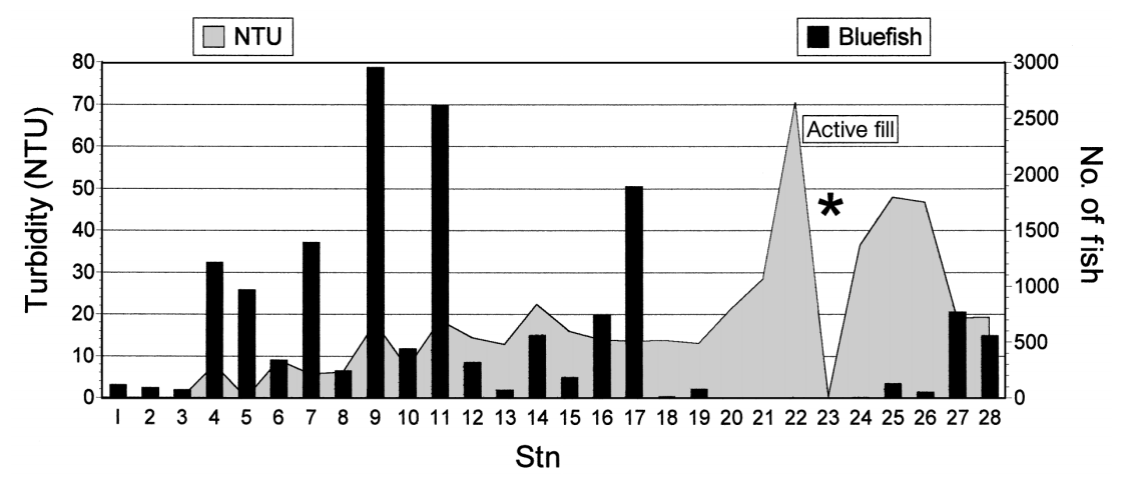

Fig. 7. Pomatomus saltatrix. Total abundance of bluefish during the September 15 to 17,1997 sampling date (black bars) and average turbidity (nephelometer turbidity units, NTU; shaded area) at each station. Asterisk denotes that no turbidity data were obtained near the active fill site, which was close to Stn 23 at the time of sampling

1997
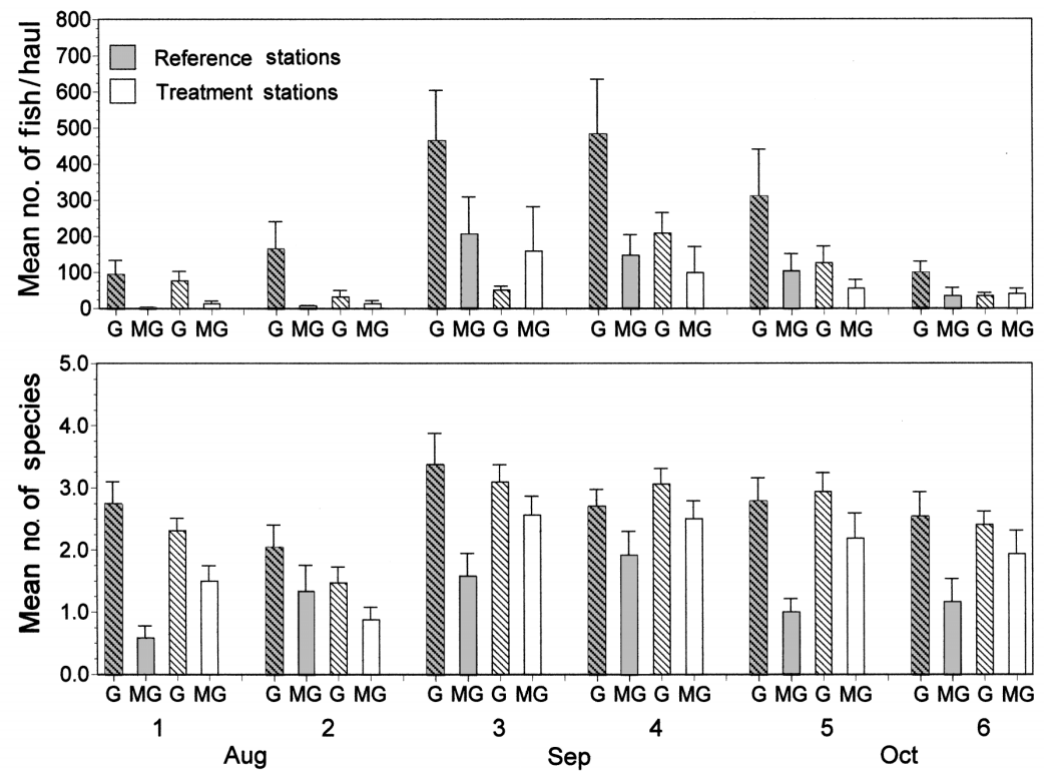

Fig. 8. Mean $( \pm \mathrm{SE})$ number of fish (top panel) and species (bottom panel) collected per haul at groin $(G$, hatched bars) and mid-groin ( $M G$, no hatching) substations at the reference (shaded bars) and treatment (open bars) stations during each sampling date in 1997

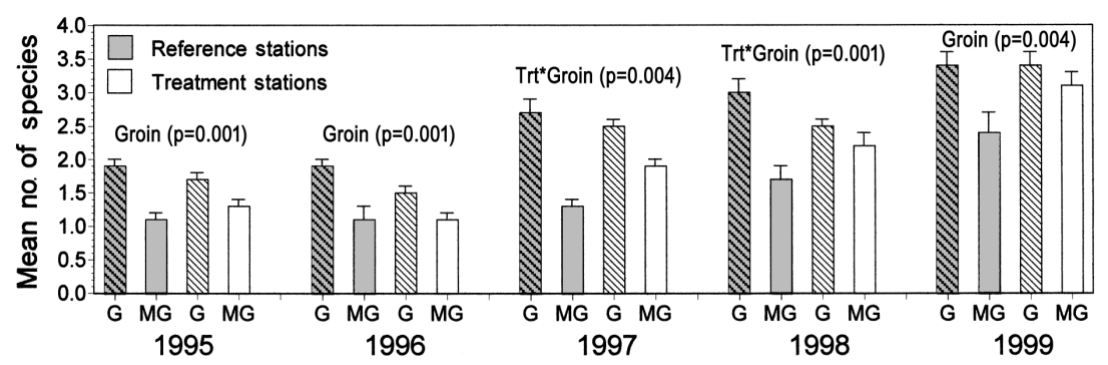

Fig. 9. Mean number of species $( \pm \mathrm{SE})$ collected per haul at groin $(G$, hatched bars) and mid-groin ( $\mathrm{MG}$, no hatching) substations in the reference (shaded bars) and treatment (open bars) stations for each year of sampling
(Fig. 10). Insects, isopods, and shrimp were among the less common identifiable Atlantic silverside prey items in 1996. Prey biomass per non-empty stomach did not differ between fish collected in the reference versus the treatment areas $(F=1.62, \mathrm{p}>0.1)$, but was significantly greater in larger Atlantic silversides $(F=11.13 \mathrm{p}=$ 0.001). The percentage of silversides with prey in their stomachs did not differ between beach areas or by fish size, averaging $91 \%$ for all fish examined (Table 7). Silversides were pooled by station in the field in 1996; therefore, potential differences in food habits associated with groin proximity were not tested.

In 1997, when the treatment area was being nourished, the type of prey consumed by Atlantic silversides was similar to that of 1996, with mole crabs comprising substantially more of the total prey biomass (Fig. 10). There were several differences in prey biomass between fish captured in the reference and treatment areas for several sampling efforts (Fig. 11). In all cases, the biomass of prey (amphipods, crab megalopae, mole crabs, and total prey biomass) was greater in silversides captured at the treatment stations (all $p$-values $<0.05$ ). The percentages of fish with non-empty stomachs ranged from 62 to $96 \%$ by sampling date and did not differ significantly between beach areas for any sampling date. Amphipods were a consistent silverside prey item for all sampling dates. Crab megalopae were present in the silversides' diet in August and early September, and mole crabs appeared in their diets in late September and October (Fig. 11). There were no differences in any prey biomass characteristics with relation to proximity of the substation to groin habitat. In 1998 and 1999, Atlantic silverside food habits remained varied, with an increase in relative copepod (averaging $22 \%$ ) prey consumption in 1998 (Fig. 10). There were no statistically significant differences in prey biomass between the beach areas for either 1998 or 1999. Also, the percentage of 
Table 5. Results of MANOVA tests of whether fish abundance in 1998 and 1999 differed between beach area (treatment, Trt), and proximity of substation to groin habitat (Groin). Results of subsequently conducted univariate 2-way ANOVAs are also shown for each response variable. Bold = significant results of interest

\begin{tabular}{|c|c|c|c|c|c|c|c|c|c|c|c|c|c|}
\hline & \multicolumn{3}{|c|}{ MANOVA } & \multicolumn{4}{|c|}{ Silversides } & \multicolumn{3}{|c|}{ Bluefish } & \multicolumn{3}{|c|}{ Rest of fish } \\
\hline & Wilk's $\lambda$ & $F$ & $\mathrm{p}$ & df & MS & $F$ & $\mathrm{p}$ & MS & $F$ & $\mathrm{p}$ & MS & $F$ & $\mathrm{p}$ \\
\hline \multicolumn{14}{|l|}{1998} \\
\hline Groin & 0.94 & 7.20 & $<0.001$ & 1 & 6.21 & 10.57 & 0.001 & 8.62 & 12.21 & 0.001 & 1.72 & 2.72 & 0.10 \\
\hline Treatment (Trt) & 0.93 & 8.24 & $<0.001$ & 1 & 6.62 & 11.26 & 0.001 & 5.26 & 7.46 & 0.007 & 4.52 & 7.18 & 0.008 \\
\hline Groin $\times$ Trt & 0.98 & 2.86 & 0.04 & 1 & 3.14 & 5.35 & 0.02 & 1.71 & 2.42 & 0.12 & 1.38 & 2.19 & 0.14 \\
\hline Error & & & & 331 & 0.59 & & & 0.71 & & & 0.63 & & \\
\hline \multicolumn{14}{|l|}{1999} \\
\hline Groin & 0.96 & 3.23 & 0.02 & 1 & 0.28 & 0.26 & 0.61 & 4.12 & 7.11 & 0.008 & 1.64 & 2.88 & 0.09 \\
\hline Treatment (Trt) & 0.96 & 3.66 & 0.01 & 1 & 5.07 & 4.67 & 0.03 & 0.08 & 0.14 & 0.71 & 1.89 & 3.32 & 0.07 \\
\hline Groin $\times$ Trt & 0.98 & 1.91 & 0.13 & 1 & 0.01 & 0.01 & 0.92 & 1.33 & 2.29 & 0.13 & 1.91 & 3.34 & 0.07 \\
\hline Error & & & & 239 & 1.08 & & & 0.58 & & & 0.57 & & \\
\hline
\end{tabular}

silversides with non-empty stomachs remained high (above $80 \%$ ) and similar between the reference and nourished areas for both years (Table 7).

\section{Rough silversides}

Rough silversides fed primarily on amphipods and copepods, although frequently the majority of the stomach contents were unidentifiable. Because over $50 \%$ of the prey biomass in rough silversides' stomachs could not be identified for samples taken in 1997, these data were not analyzed statistically. Copepods, amphipods, and polychaetes were consistently major rough silverside prey items in all years of sampling, with dipteran insects present in 1998, and mole crabs present in 1998 and 1999. As with Atlantic silversides, the amphipod Jassa falcata was the most common amphipod observed in the amphipod biomass, however Gammarus annulatus was commonly present.

\section{Northern kingfish}

Annelids were the predominant northern kingfish prey item in terms of biomass for all years of sampling (Fig. 12), and the polychaete Scolelepis squamata was the most common species encountered in annelid biomass. The kingfish diet was also varied, with amphipods, shrimp, mysids, isopods, and juvenile mole crabs comprising other parts of the diet. There were no significant differences in any food habit variables for kingfish captured in the reference versus the treatment areas in 1996. Likewise, stomach fullness did not differ between beach areas, and the percentage of kingfish with non-empty stomachs, which was greater than $80 \%$, did not differ significantly between beach areas (Table 7).
Although kingfish were captured during all 6 sampling dates in 1997, stomach contents were not analyzed for the early August sampling date, in which almost all individuals captured were less than $5 \mathrm{~cm}$ SL. Annelid prey biomass was significantly greater in kingfish captured during the second sampling date of 1997 at the treatment stations $(F=9.6, \mathrm{p}<0.01$, Fig. 13), comprising $82 \%$ of the total prey biomass compared to $51 \%$ for fish from the reference stations. The percentage of kingfish with prey in their stomachs (Table 7) and total prey biomass did not differ based on capture location in 1997. The polychaete Scolelepis squamata dominated the diets of kingfish

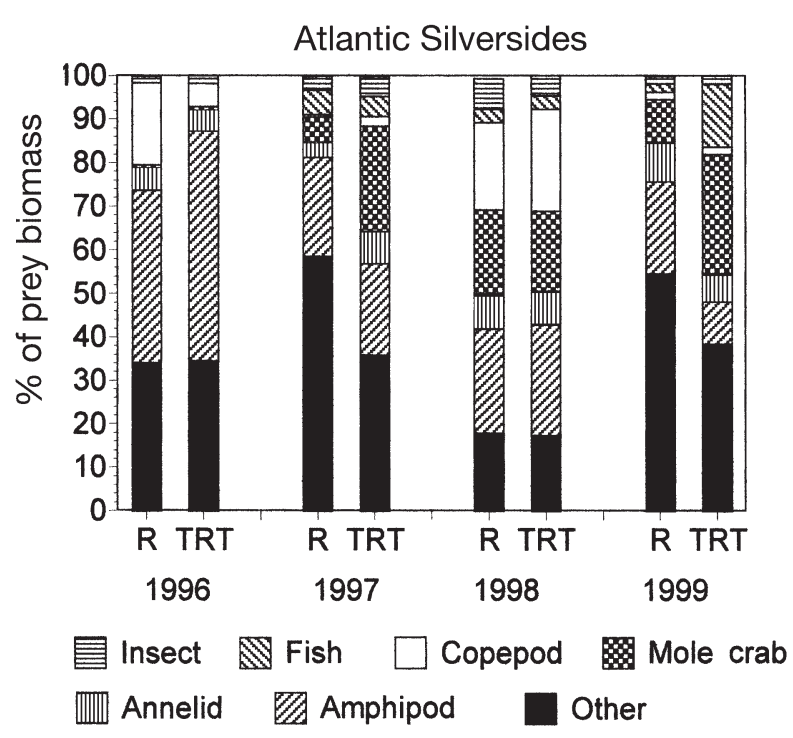

Fig. 10. Menidia menidia. Stacked histogram bars depicting the relative proportions of each major prey category in the diets of Atlantic silversides captured at the reference (R) and treatment (TRT) areas from 1996 to 1999 
Table 6. Menidia menidia. Presence of different prey taxa in 2 size classes of Atlantic silversides. Each X signifies that at least 1 prey item from that category was present. Sample sizes indicate the number of non-empty fish stomachs examined. (LPIL) signifies the lowest practical identification level. Prey taxa include the following identifications: crab: Emerita talpoida, larval megalopae; shrimp: Crangon septemspinosa; amphipod: Jassa falcata, Hyale plumulosa, Gammarus annulatus, Haustoriidae (LPIL); isopod: Jaera marina, Idotea balthica; mysid: Neomysis americana; insect: Telmatogeton, diptera (LPIL), flying ants; polychaete: Scolelepis squamata, Phyllodoce (LPIL), Nephthys bucera, Polynoidae (LPIL), Scoletoma acicularum; bivalve: Mytilus edulis

\begin{tabular}{|c|c|c|c|c|c|c|c|c|}
\hline \multirow[b]{2}{*}{ Prey taxon ${ }^{1}$} & \multicolumn{4}{|c|}{ Atlantic silversides $(<60 \mathrm{~mm})$} & \multicolumn{4}{|c|}{ Atlantic silversides ( $\geq 60 \mathrm{~mm})$} \\
\hline & $\begin{array}{c}1996 \\
(\mathrm{n}=1709)\end{array}$ & $\begin{array}{c}1997 \\
(\mathrm{n}=1244)\end{array}$ & $\begin{array}{c}1998 \\
(\mathrm{n}=1844)\end{array}$ & $\begin{array}{c}1999 \\
(\mathrm{n}=2924)\end{array}$ & $\begin{array}{c}1996 \\
(\mathrm{n}=1371)\end{array}$ & $\begin{array}{c}1997 \\
(\mathrm{n}=2619)\end{array}$ & $\begin{array}{c}1998 \\
(\mathrm{n}=2742)\end{array}$ & $\begin{array}{c}1999 \\
(\mathrm{n}=5705)\end{array}$ \\
\hline Crab & $\mathrm{X}$ & $\mathrm{X}$ & $\mathrm{X}$ & $\mathrm{X}$ & $\mathrm{X}$ & $\mathrm{X}$ & $\mathrm{X}$ & $\mathrm{X}$ \\
\hline Shrimp & $\mathrm{X}$ & & & $\mathrm{X}$ & $\mathrm{X}$ & & $\mathrm{X}$ & $\mathrm{X}$ \\
\hline Amphipod & $\mathrm{X}$ & $\mathrm{X}$ & $\mathrm{X}$ & $\mathrm{X}$ & $\mathrm{X}$ & $\mathrm{X}$ & $\mathrm{X}$ & $\mathrm{X}$ \\
\hline Isopod & & & & & $\mathrm{X}$ & $\mathrm{X}$ & & $\mathrm{X}$ \\
\hline Mysid & & & $\mathrm{X}$ & & & & $\mathrm{X}$ & \\
\hline Insect & & $\mathrm{X}$ & $\mathrm{X}$ & $\mathrm{X}$ & $\mathrm{X}$ & $\mathrm{X}$ & $\mathrm{X}$ & $\mathrm{X}$ \\
\hline Polychaete & $\mathrm{X}$ & $\mathrm{X}$ & $\mathrm{X}$ & $\mathrm{X}$ & $\mathrm{X}$ & $\mathrm{X}$ & $\mathrm{X}$ & $\mathrm{X}$ \\
\hline Bivalve & & & & & & & & $\mathrm{X}$ \\
\hline
\end{tabular}

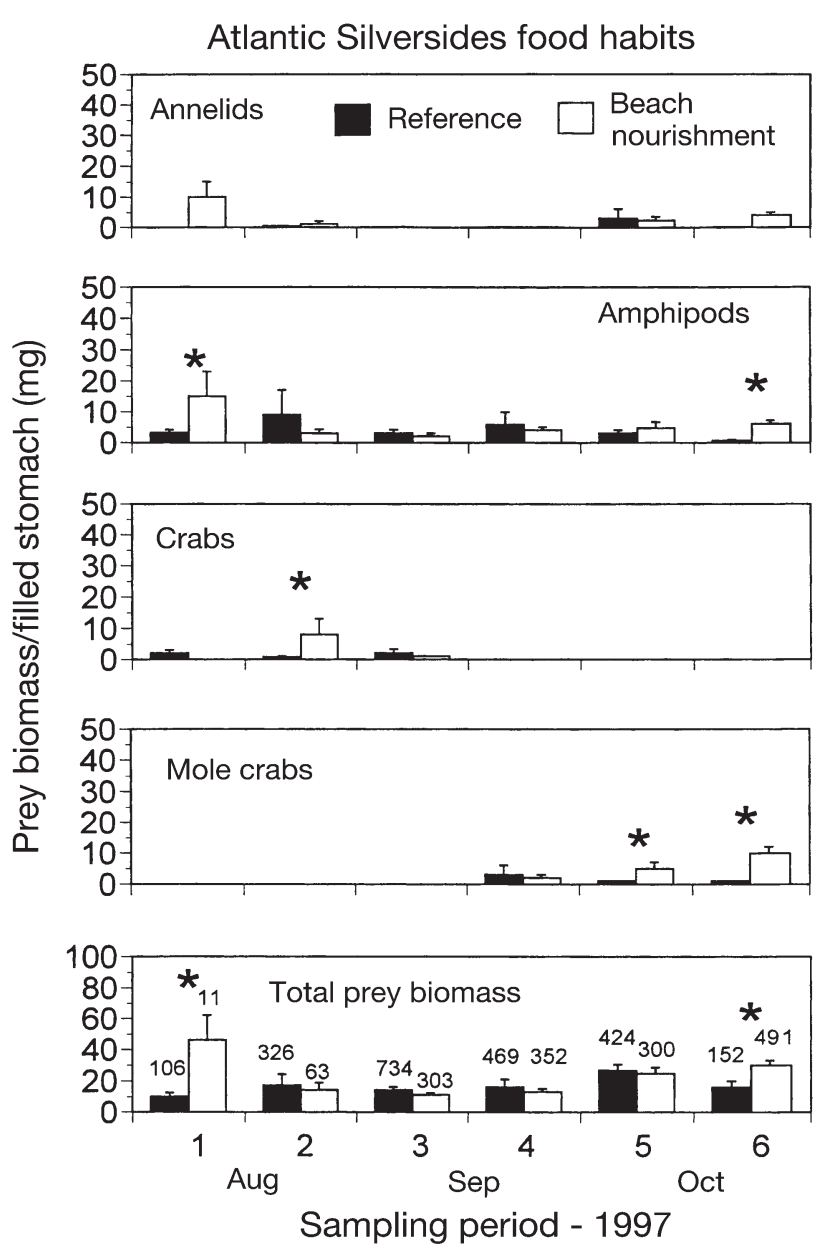

Fig. 11. Menidia menidia. Average prey biomass (mg) per non-empty stomach by major prey category for Atlantic silversides captured at reference (black bars) and treatment (white bars) in 1997. Numbers over the bars in the bottom panel indicate the number of non-empty stomachs examined.

* Significant difference between treatments $(\mathrm{p}<0.05)$ captured in August and September, and mole crabs were predominant in the diet of the few kingfish captured at the reference stations in October (Fig. 13). The prey composition of kingfish diets in 1998 and 1999 were similar to that of previous years (Fig. 12, Table 8) and did not exhibit any consistent differences between the reference and treatment areas. In 1999, kingfish were only caught in sufficient numbers to permit statistical analysis of food habits data for the first sampling date of October. Thus, the relatively high biomass of prey per non-empty stomach may be due to a higher proportion of larger fish compared to other years.

\section{Water quality}

Turbidity measurements ranged from 2 to 70 NTU in 1997, with a median value of 12 NTU. There was a significant interaction between sampling date and reference versus treatment area $(F=3.0, \mathrm{p}<0.05)$. Elevated turbidity was not always associated with the timing or location of sand being discharged onto the beach (Fig. 14). For example, sand was being discharged onto the beach at Stns 16 to 18 during the August 4 to 7,1997 sampling dates, and the turbidity at these stations was relatively low, ranging from 9 to 12 NTU (Figs. 6 \& 14). During the second 1997 sampling date, turbidity was relatively high (53 NTU) at 2 stations (27 and 28) near the mouth of the Manasquan inlet, which was also the site of sand placement on the beach $3 \mathrm{~d}$ prior to sampling. During the third sampling date, turbidity at a single station at the mouth of the Shark River inlet averaged 68 NTU, whereas turbidity ranged from 10 to 19 NTU at Stns 24 to 28, where beach nourishment was occurring. Turbidity 
Table 7. Average prey biomass per non-empty stomach (Biomass), percentage of non-empty stomachs (\% filled) and number of stomachs examined (n) for Atlantic silversides Menidia menidia and northern kingfish Menticirrhus saxatilis from 1996 to 1999. R: reference area; $\mathrm{T}$ : treatment area

\begin{tabular}{|c|c|c|c|c|c|c|c|c|c|}
\hline \multirow[t]{2}{*}{ Species } & & \multicolumn{2}{|c|}{1996} & \multicolumn{2}{|c|}{1997} & \multicolumn{2}{|c|}{1998} & \multicolumn{2}{|c|}{1999} \\
\hline & & $\mathrm{R}$ & $\mathrm{T}$ & $\mathrm{R}$ & $\mathrm{T}$ & $\mathrm{R}$ & $\mathrm{T}$ & $\mathrm{R}$ & $\mathrm{T}$ \\
\hline \multirow[t]{3}{*}{ Atlantic silversides } & Biomass & 0.016 & 0.015 & 0.019 & 0.025 & 0.184 & 0.134 & 0.049 & 0.079 \\
\hline & $\%$ filled & 91 & 91 & 81 & 87 & 87 & 83 & 84 & 81 \\
\hline & $\mathrm{n}$ & 2135 & 1257 & 2745 & 1751 & 2876 & 2497 & 3495 & 7033 \\
\hline \multirow[t]{3}{*}{ Northern kingfish } & Biomass & 0.058 & 0.045 & 0.072 & 0.092 & 0.25 & 0.19 & 0.549 & 0.312 \\
\hline & $\%$ filled & 83 & 92 & 83 & 79 & 79 & 88 & 92 & 90 \\
\hline & $\mathrm{n}$ & 125 & 34 & 265 & 799 & 641 & 699 & 131 & 292 \\
\hline
\end{tabular}

was 70 NTU at Stns 22 and 23, where sand was being discharged during the fourth (September 15 to 17) sampling date, and was low elsewhere (Figs. $7 \& 14$ ). Turbidities reached 51 NTU in the reference area during the fifth sampling date, and over 60 NTU at Stns 13 and 14 (near Shark River Inlet) during the sixth sampling date (Fig. 14). These sites were not in close proximity to a nourishment event.

In 1998, turbidity ranged from 2 to 87 NTU, with a median value of 9 NTU. Relatively high turbidities (>60 NTU) were recorded only during the second sampling date at 3 stations near the mouth of the Manasquan Inlet. In 1999, turbidity ranged from $<5$ to 54 NTU, with a median of 8 NTU. The higher turbidity readings were not associated with any weather-related conditions or discharge from either the Shark River or Manasquan Inlets during the sampling undertaken in 1999.

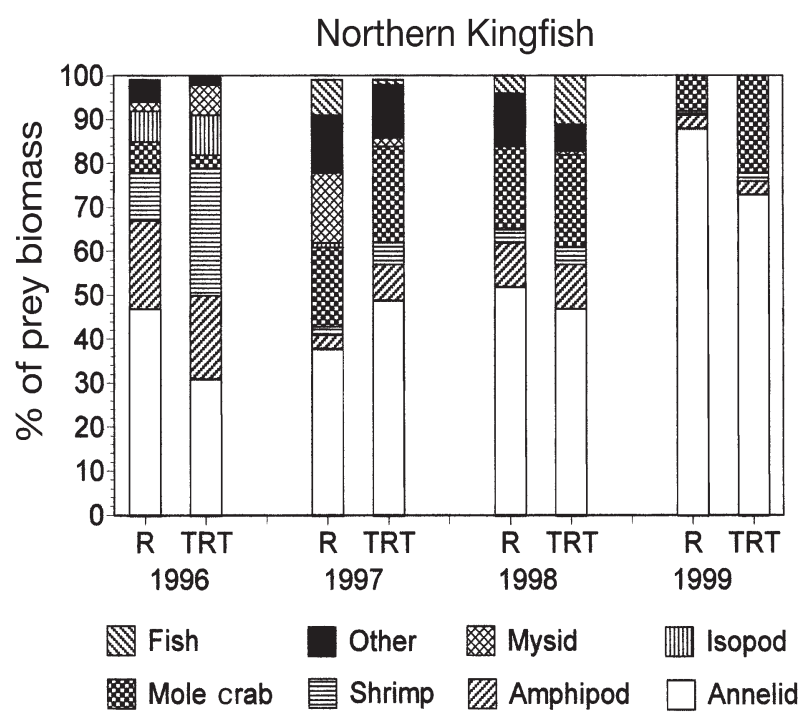

Fig. 12. Menticirrhus saxatilis. Stacked histogram bars depicting the relative proportions of each major prey category in the diets of northern kingfish captured at the reference (R) and treatment (TRT) areas from 1996 to 1999

\section{DISCUSSION}

Previous findings that surf-zone fish assemblages are highly variable and dominated by large numbers of juvenile fish representing few species (Modde 1980, Lasiak 1981, 1984, Ayvazian \& Hyndes 1995, Gibson et al. 1996) were also observed in this study. Variation in

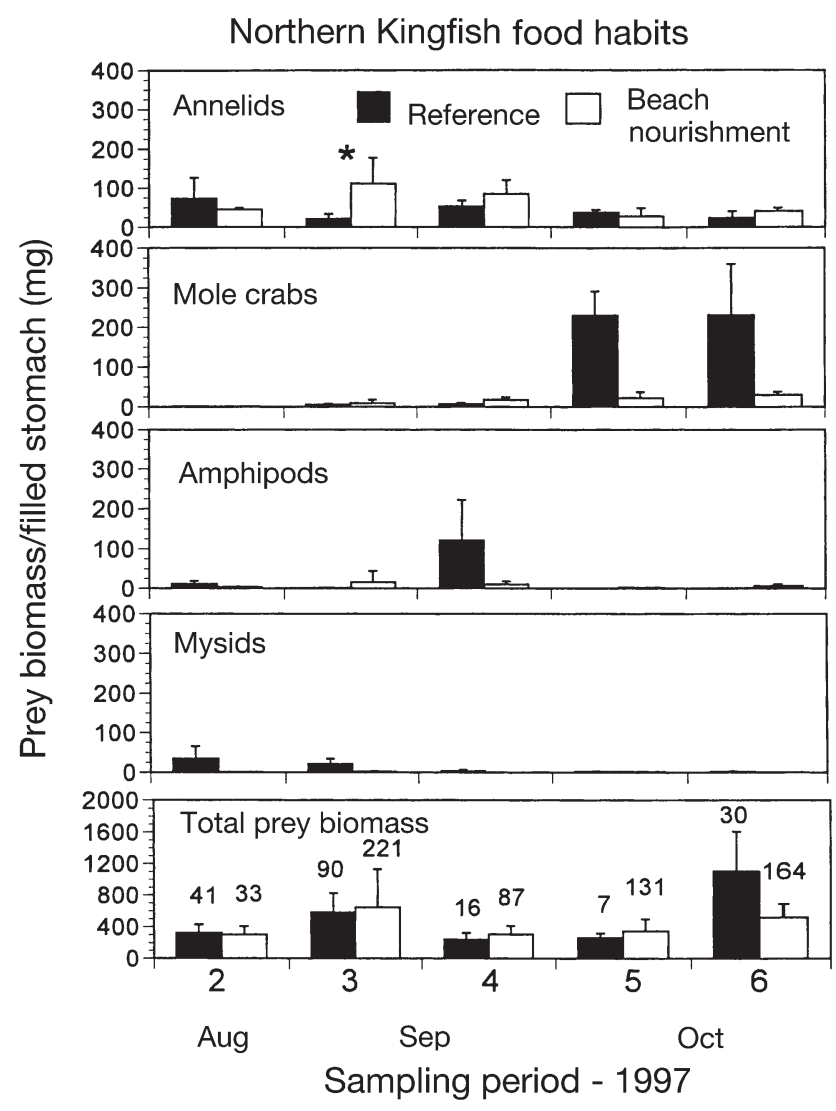

Fig. 13. Menticirrhus saxatilis. Average prey biomass (mg) per non-empty stomach by major prey category for kingfish captured at reference (black bars) and treatment (white bars) in 1997. Numbers over the bars in the bottom panel indicate the number of non-empty stomachs analyzed. ${ }^{*}$ Significant difference between treatments $(\mathrm{p}<0.01)$ 
Table 8. Menticirrhus saxatilis. Presence of different prey taxa in 3 size classes of northern kingfish. Each X signifies that at least 1 prey item from that category was present. Sample sizes indicate the number of non-empty fish stomachs examined. Prey identifications within each prey taxon are given in the legend of Table 6. SL: standard length

\begin{tabular}{|c|c|c|c|c|c|c|c|c|c|c|c|c|}
\hline \multirow[t]{2}{*}{ Prey taxon } & \multicolumn{4}{|c|}{ Kingfish (5-9.9 cm SL) } & \multicolumn{4}{|c|}{ Kingfish $(10-14.9 \mathrm{~cm}$ SL) } & \multicolumn{4}{|c|}{ Kingfish (15-19.9 cm SL) } \\
\hline & $\begin{array}{c}1996 \\
(\mathrm{n}=132)\end{array}$ & $\begin{array}{c}1997 \\
(\mathrm{n}=754)\end{array}$ & $\begin{array}{c}1998 \\
(\mathrm{n}=546)\end{array}$ & $\begin{array}{c}1999 \\
(\mathrm{n}=201)\end{array}$ & $\begin{array}{c}1996 \\
(\mathrm{n}=3)\end{array}$ & $\begin{array}{c}1997 \\
(\mathrm{n}=65)\end{array}$ & $\begin{array}{c}1998 \\
(\mathrm{n}=288)\end{array}$ & $\begin{array}{c}1999 \\
(\mathrm{n}=123)\end{array}$ & $\begin{array}{c}1996 \\
(\mathrm{n}=0)\end{array}$ & $\begin{array}{c}1997 \\
(\mathrm{n}=1)\end{array}$ & $\begin{array}{c}1998 \\
(\mathrm{n}=28)\end{array}$ & $\begin{array}{c}1999 \\
(\mathrm{n}=61\end{array}$ \\
\hline Crab & $\mathrm{X}$ & $X$ & $\mathrm{X}$ & $\mathrm{X}$ & & $\mathrm{X}$ & $\mathrm{X}$ & $\mathrm{X}$ & & & & $\mathrm{X}$ \\
\hline Shrimp & $\mathrm{X}$ & $\mathrm{X}$ & $\mathrm{X}$ & $\mathrm{X}$ & $\mathrm{X}$ & $\mathrm{X}$ & $\mathrm{X}$ & $\mathrm{X}$ & & & $\mathrm{X}$ & $\mathrm{X}$ \\
\hline Amphipod & $X$ & $X$ & $\mathrm{X}$ & $\mathrm{X}$ & & $\mathrm{X}$ & $\mathrm{X}$ & $\mathrm{X}$ & & $X$ & $\mathrm{X}$ & $\mathrm{X}$ \\
\hline Isopod & $X$ & $X$ & & & $\mathrm{X}$ & $\mathrm{X}$ & & & & & & \\
\hline Mysid & & $X$ & $X$ & & & & & & & & & \\
\hline Insect & & & & & $\mathrm{X}$ & & & & & & & \\
\hline Polychaete & $\mathrm{X}$ & $\mathrm{X}$ & $\mathrm{X}$ & $\mathrm{X}$ & $X$ & $X$ & $\mathrm{X}$ & $X$ & & & $\mathrm{X}$ & $\mathrm{X}$ \\
\hline Bivalve & & & $\mathrm{X}$ & & & & & & & & & \\
\hline
\end{tabular}

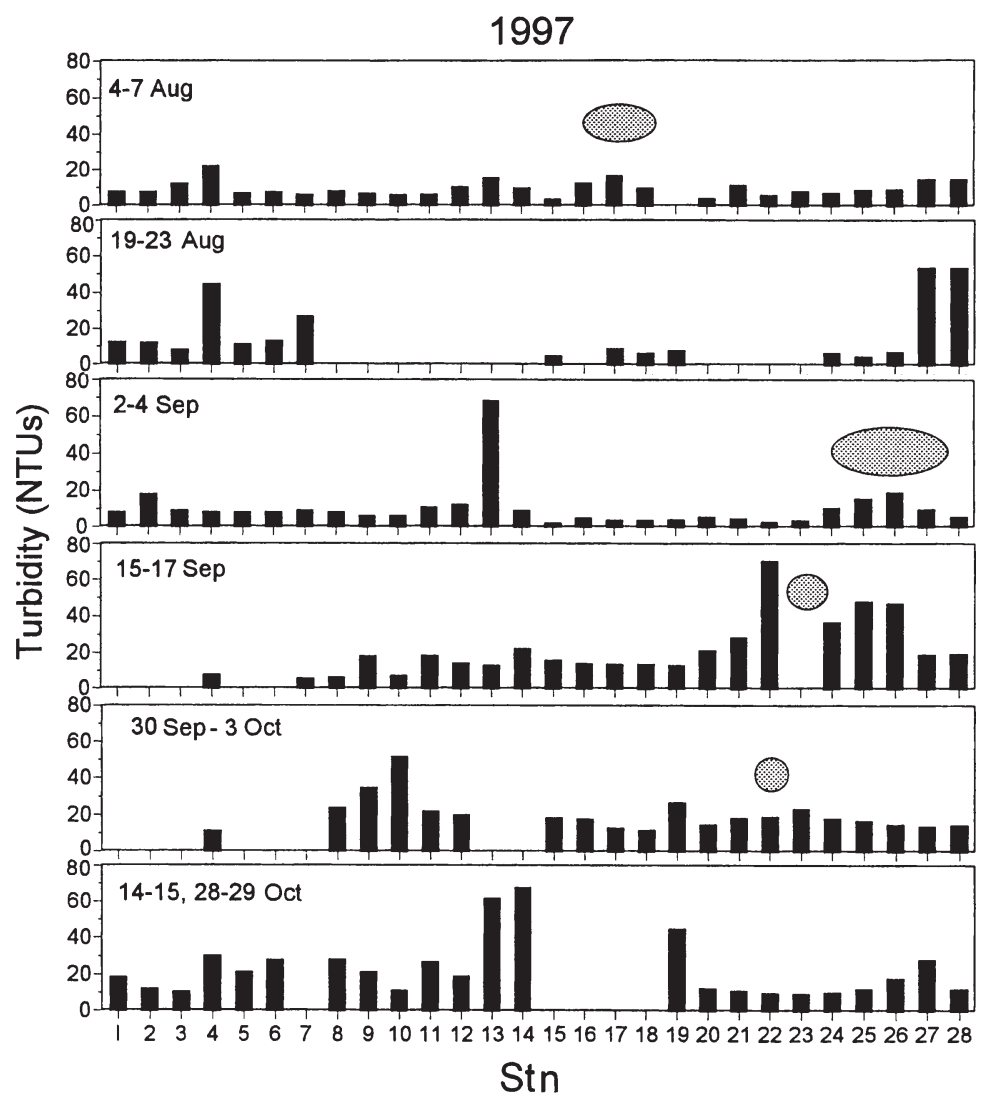

Fig. 14. Average turbidity (nephelometer turbidity units, NTU) of each station at the time of sampling in 1997. Shaded ovals over the histogram bars indicate the location of sand placement on the beach if nourishment was occurring during the sampling effort

these surf-zone fish assemblages can be viewed hierarchically from the large-scale, interannual fluctuations that reflect variation in year class strength, to more moderate fluctuations that occur in response to seasonal factors, to small-scale, localized variation that occurs in response to physico-chemical factors (sal- inity, temperature, turbidity, wave height, etc.; Ross et al. 1987). Detecting potential changes in fish distribution and abundance in response to a physical disturbance, such as beach nourishment, against the higherorder levels of background variation, has not been previously addressed in the literature (Hackney et al. 1996, Ross \& Lancaster 2002) and was approached with an intensive sampling effort in this study. The hierarchical framework proposed by Ross et al. (1987) for surf zone fishes was evident in the results of this study, although seasonal variation was not pronounced given the abbreviated duration of sampling each year. Interannual fluctuations in relative species abundance resulted in a shift from a community numerically dominated by silversides during the baseline years, to one in which bluefish were most numerous during the beach nourishment year (1997), when bluefish abundance increased 10-fold (Fig. 2).

Smaller-scale variation in fish distribution patterns, perhaps in response to localized physical conditions, was also evident in 1997. Bluefish abundances were higher at reference stations and low near active beach fill operations (Fig. 7). There was not a similar reduction in the number of other species near the fill site at the same time, suggesting that bluefish may be more sensitive to beach nourishment alterations, and therefore avoided the area. The likelihood that localized low bluefish numbers reflect mortality related to the beach nourishment project is doubtful, given that highly mobile bluefish are capable of avoiding unfavorable conditions (Pottern et al. 1989), and there was no evidence that mortality had occurred. Turbidity at 
the active fill site (Fig. 7) was elevated, averaging 70 NTU, which may have reduced the suitability of this area for visual foraging by bluefish. The physiological and behavioral responses of bluefish to protracted exposures of elevated suspended sediment concentrations are not known (Wilber \& Clarke 2001).

In contrast, northern kingfish appeared to respond on occasion to the sand placement activity by congregating near these sites. For example, $70 \%$ of the kingfish captured during the August 4 to 7 sampling date (Fig. 6) were caught near Stns 16 and 17, which were undergoing active sand replenishment. Turbidity at these stations, however, was not elevated (Fig. 14). Kingfish captured during this sampling date were in the smallest size category ( $<5 \mathrm{~cm} \mathrm{SL})$, and their stomach contents were not analyzed. During the second sampling date, kingfish captured at the treatment stations contained significantly more polychaete prey biomass than kingfish captured at reference stations (Fig. 13), which may reflect increased availability of these prey items following sand placement on the beach. These findings are consistent with the higher abundances and greater site fidelity of tagged gulf kingfish Menticirrhus littoralis captured by beach seine along recently nourished beaches in North Carolina (Ross \& Lancaster 2002).

Localized fish abundance and distribution patterns were significantly associated with the presence of the rock groins, with greater fish captures and higher species richness at substations nearest the groins. The presence of the rock groins may have increased the sampling efficiency near these structures, resulting in more abundant and species-rich catches. Alternatively, groin habitat may provide a foraging site and shelter for fishes in the surf zone, and is associated with higher fish abundances and species richness in other surf zone communities (Peters \& Nelson 1987, Clark et al. 1996). In 1997 and 1998, the greater fish abundance (Fig. 3) and richness (Fig. 9) at groin substations compared to mid-groin substations was more enhanced in the reference area. Partial burial of the rock groins by the nourishment operation may have temporarily reduced their habitat value in the treatment area. Rock groins may provide forage in the form of amphipods such as Hyale plumulosa and larvae of the chironomid fly Telmatogeton. Both were common in qualitative scrapings of rock groin substrata and in Atlantic silverside diets for all years (Table 6). Fish foraging near the groins most probably fed on animals dislodged from the rock groins by wave action, as evidenced by the presence of both taxa in plankton samples (our Table 9, Burlas et al. 2001). The biomass of prey did not differ between silversides caught at the groin substations and the mid-groin substations when data were sufficient for analysis by this variable, which probably reflected substantial movement of silversides within the groin field. There was no evidence that burial of the groin habitat significantly affected feeding habits of the surf zone fish examined. In contrast, burial of nearshore hardbottom habitat in SE Florida by dredged material reduced the number of individuals and species of

Table 9. Taxa collected in Atlantic silverside Menidia menidia and northern kingfish Menticirrhus saxatilis stomach contents and rank order abundance (visually estimated) in sampled habitats. (+) indicates the taxon was present but not among the 10 most abundant taxa. (LPIL) signifies the lowest practical identification level

\begin{tabular}{|c|c|c|c|c|c|c|}
\hline Taxon & $\begin{array}{l}\text { Stomach } \\
\text { contents }\end{array}$ & $\begin{array}{l}\text { Rocky } \\
\text { groins }\end{array}$ & $\begin{array}{l}\text { Surf zone } \\
\text { plankton }\end{array}$ & $\begin{array}{l}\text { Intertidal } \\
\text { benthos }\end{array}$ & $\begin{array}{c}\text { Nearshore } \\
\text { benthos }\end{array}$ & $\begin{array}{l}\text { Offshore } \\
\text { benthos }\end{array}$ \\
\hline Brachyura (LPIL) & + & & & + & + & + \\
\hline Copepoda (LPIL) & + & & 1 & & & \\
\hline Crab Megalops (LPIL) & + & & 3 & & & \\
\hline Crangon septemspinosa & + & & 7 & + & & + \\
\hline Diptera (LPIL) & + & & & & & \\
\hline Emerita talpoida & + & & + & 8 & + & \\
\hline Gammarus annulatus & + & & 2 & + & + & + \\
\hline Haustoriidae (LPIL) & + & & & 10 & 5 & + \\
\hline Hyale plumulosa & + & 3 & + & & & \\
\hline Idotea balthica & + & & 10 & & + & \\
\hline Terrestrial Insects & + & & 6 & & & \\
\hline Jaera marina & + & & & & & + \\
\hline Jassa falcata & + & & + & + & + & + \\
\hline Mytilus edulis & + & 2 & 4 & 4 & 10 & + \\
\hline Neomysis americana & + & & + & & + & + \\
\hline Nephthys bucera & + & & & + & + & + \\
\hline Scolelepis squamata & + & & + & 2 & + & \\
\hline Scoletoma acicularum & + & & & & & + \\
\hline Telmatogeton (LPIL) & + & 4 & + & & & \\
\hline
\end{tabular}


juvenile fish in the area where the dredged material was placed (Lindeman \& Snyder 1998). The disparate results of these 2 studies, along with the scarcity of published studies that address beach nourishment impacts on fish, illustrate the need for caution when extrapolating results beyond the habitat type, species composition, and project characteristics of a given study.

The considerable flexibility in foraging habits of surf zone fishes (McDermott 1983, Lasiak \& McLachlan 1987, McMichael \& Ross 1987, DeLancey 1989) may, at least in part, explain why fish food habits were not negatively affected by the beach nourishment project. Comparison of common food items with potential habitat sources suggests that both Atlantic silversides and northern kingfish consumed prey from a variety of different habitats (Table 9). Atlantic silversides, which are considered planktivores (Bengtson 1984), fed heavily on benthic amphipods and polychaetes and also ingested insects, such as the larvae of the groin-associated chironomid Telmatogeton and flying ants. Insects striking the water's surface after being carried offshore by winds may represent a small but consistent food supply. The dominance in the northern kingfish diet of the amphipod Jassa falcata, which is found most abundantly in offshore sediments (Burlas et al. 2001), along with groin-associated and terrestrial taxa in Atlantic silversides diets, suggests that if surf zone benthic habitat is temporarily disturbed, these fish can shift prey consumption to other resources. There was no evidence that the beach nourishment project reduced prey consumption of any type (Figs. 11 \& 13). In fact, the biomass of both benthic (polychaetes and mole crabs) and planktonic (amphipods and crab megalopae) prey was greater in fish captured at treatment stations in 1997.

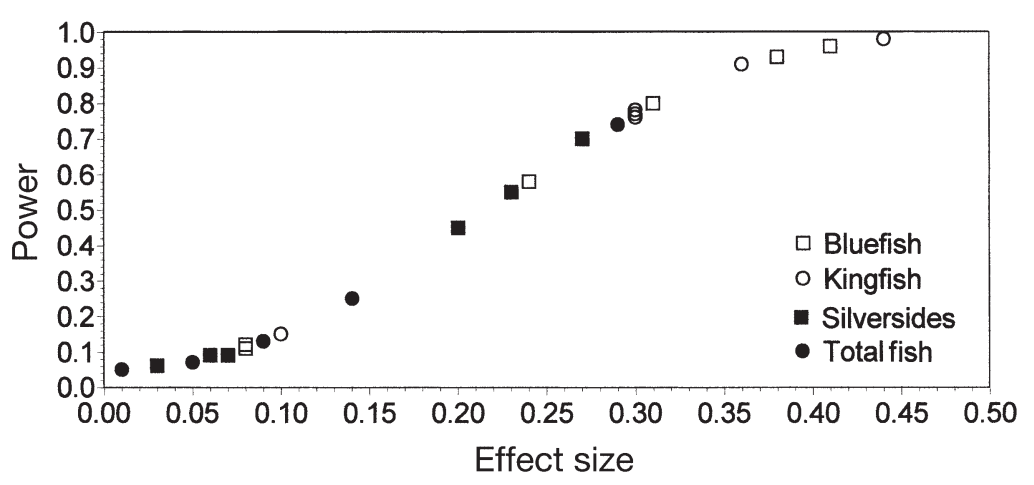

Fig. 15. Statistical power to detect a given effect size (SD of means divided by overall SD) as calculated for 1-factor ANOVAs (reference vs treatment areas) for each sampling date in 1997 for bluefish Pomatomus saltatrix (ם), northern kingfish Menticirrhus saxatilis (o), Atlantic silversides Menidia menidia and Membras martinica (घ), and total fish abundance (•)

\section{CONCLUSIONS}

Reliably detecting human effects on natural populations is a difficult undertaking in many monitoring studies. Low, or non-existent, spatial replication of the impact, coupled with high natural variation, can result in the use of monitoring programs that may be costefficient, but are inadequate in terms of sampling design (Underwood 1992). Some researchers advocate retrospective power analysis (Peterman 1990, Fairweather 1991) as a tool to assess whether a monitoring effort was sufficient to detect impacts if they had occurred. Not only can the realized power of a study be determined (e.g. Osenberg et al. 1994, Thomas \& Juanes 1996), but also the detectable effect size, or magnitude of difference needed to produce a significant result (e.g. Rotenberry \& Wiens 1985) can be estimated. Although these a posteriori analyses are not universally recommended (Hoenig \& Heisey 2001), we examine effect size and power for this monitoring study because it is useful to see how effective this uncommonly large expenditure of effort (2190 seine hauls over $5 \mathrm{yr}$ ) was in assessing potential impacts to the surf-zone fish population. Effect sizes (standard deviation between means divided by the overall standard deviation) calculated on mean abundance of fish captured in reference versus treatment areas were largest for bluefish and northern kingfish in 1997 (Fig. 15), whereas smaller effect sizes were predominantly observed for silversides and total fish abundance. When averaged over the 6 sampling dates in 1997, the detectable effect sizes for bluefish, kingfish, silversides, and total fish abundance were 3.5, 2.0, 2.9, and 3.2 , respectively. In other words, approximately a 3-fold difference in mean abundance was needed between reference and treatment fish catches to produce a statistically significant result. Therefore, if a theoretical $50 \%$ reduction in fish abundance was deemed biologically relevant in this study, given the background variation, the sampling protocol, although unprecedented in its level of effort, was insufficient to detect such a difference. There is little available guidance on what scale of change in fish abundance should be considered meaningful. Direct mortality of fishes due to exposure to nourishment-induced disturbance in this project was not observed. Changes in localized abundance (bluefish and kingfish) appeared to reflect more subtle attraction or avoidance responses to varying suspended sediment concentrations. Consequently, the interpretation of meaningful effect size is not simply detection of a $10,50 \%$, or greater change, but the realization that observed 
reductions in fish abundance (if any are detected) might have no other meaning than the fact that mobile fishes have moved beyond the bounds of sampling stations.

Benthic sampling is the most frequently required component of beach-nourishment monitoring projects, in part, because of the inherent difficulties in sampling fishes relative to collecting benthic organisms. Yet, if a temporary reduction in benthos does not detrimentally affect prey consumption of fish that forage in the nourished area, as was the result of this study, then continued mandatory benthic monitoring does not appear to be a prudent use of limited monitoring resources. Likewise, using fish abundance as an indicator of potential impacts in highly variable surf-zone fish assemblages is likely to produce inconclusive results. Future monitoring efforts may benefit from focusing on specific mechanisms of impacts to species of concern, such as the physical condition of fish captured in the vicinity of the sediment plume.

Acknowledgements. We greatly appreciate the substantial field and logistical support provided by Howard Ruben and Bob Will (US Army Engineer District, New York), data management by Patty Tolley, and sampling design by Pace Wilber. Barry Vittor and associates assisted with taxonomic identification of the food habits and plankton samples. This paper greatly benefited from the careful review of C. H. Peterson.

\section{LITERATURE CITED}

Able KW, Rowe P, Burlas M, Byrne D (in press) Use of ocean and estuarine habitats by young-of-the-year bluefish (Pomatomus saltatrix) in the New York Bight, USA. Fish Bull

Ayvazian SG, Hyndes GA (1995) Surf-zone fish assemblages in south-western Australia: do adjacent nearshore habitats and the warm Leeuwin Current influence the characteristics of the fish fauna? Mar Biol 122:527-536

Bengtson DA (1984) Resource partitioning by Menidia menidia and Menidia beryllina (Osteichthyes: Atherinidae). Mar Ecol Prog Ser 18:21-30

Bennett BA (1989) Fish community of a moderately exposed beach on the southwestern Cape coast of South Africa and an assessment of this habitat as a nursery for juvenile fish. Estuar Coast Shelf Sci 28:293-305

Beyst B, Hostens K, Mees J (2001) Factors influencing fish and macrocrustacean communities in the surf zone of sandy beaches in Belgium: temporal variation. J Sea Res 46: 281-294

Borgeson DP (1963) A rapid method for food habit studies. Trans Am Fish Soc 92:434-435

Briggs PT (1975) Shore-zone fishes of the vicinity of Fire Island inlet, Great South Bay, New York. NY Fish Game J 22:1-12

Burlas M, Ray GL, Clarke DG (2001) The New York district's biological monitoring program for the Atlantic coast of New Jersey, Asbury Park to Manasquan Section beach erosion control project. Final report. US Army Engineer District, New York, and US Army Engineer Research and Development Center, Waterways Experiment Station, Vicksburg, MS. Available at www.nan.usace.army.mil/ business/prjlinks/coastal/Asbury/index.htm
Clark BM, Bennett BA, Lamberth SJ (1996) Factors affecting spatial variability in seine net catches of fish in the surf zone of False Bay, South Africa. Mar Ecol Prog Ser 131: $17-34$

DeLancey LB (1989) Trophic relationship in the surf zone during the summer at Folly Beach, South Carolina. J Coast Res 5:477-488

Fairweather PG (1991) Statistical power and design requirements for environmental monitoring. Aust J Mar Freshw Res 42:555-567

Gibson RN, Robb L, Burrows MT, Ansell AD (1996) Tidal, diel and longer term changes in the distribution of fishes on a Scottish sandy beach. Mar Ecol Prog Ser 130:1-17

Hackney CT, Posey MH, Ross SW, Norris AR (1996) A review and synthesis of data on surf zone fishes and invertebrates in the South Atlantic Bight and the potential impacts from beach nourishment. Contract Report to the US Army Engineer Wilmington District, Wilmington, NC

Hintze JL (2000) PASS user's guide. NCSS Trial and PASS 2000, Kaysville, UT

Hoenig JM, Heisey DM (2001) The abuse of power: the pervasive fallacy of power calculations for data analysis. Am Stat 55:19-24

Jutte PC, Van Dolah RF, Levisen MV (1999) An environmental monitoring study of the Myrtle Beach Renourishment Project: intertidal benthic community assessment of Phase II, Myrtle Beach. Supplemental Report. Prepared for US Army Corps of Engineers, Charleston. Marine Resources Division, South Carolina Department of Natural Resources, Charleston, SC

LaSalle MW, Clarke DG, Homziak J, Lunz JD, Fredette TJ (1991) A framework for assessing the need for seasonal restrictions on dredging and disposal operations. Technical Report D-91-1. US Army Engineer Waterways Experiment Station, Vicksburg, MS

Lasiak TA (1981) Nursery grounds of juvenile teleosts: evidence from the surf zone of King's Beach, Port Elizabeth. S Afr J Sci 77:388-390

Lasiak TA (1984) Structural aspects of the surf-zone fish assemblage at King's Beach, Algoa Bay, South Africa: long-term fluctuations. Estuar Coast Shelf Sci 18:459-483

Lasiak TA (1986) Juveniles, food and the surf zone habitat: implications for teleost nursery areas. S Afr J Zool 21: $51-56$

Lasiak TA, McLachlan A (1987) Opportunistic utilization of mysid shoals by surf-zone teleosts. Mar Ecol Prog Ser 37: $1-7$

Layman CA (2000) Fish assemblage structure of the shallow ocean surf-zone on the eastern shore of Virginia barrier islands. Estuar Coast Shelf Sci 51:201-213

Lazzari MA, Sherman S, Brown CS, King J, Joule BJ, Chenoweth SB, Langton RW (1999) Seasonal and annual variations in abundance and species composition of two nearshore fish communities in Maine. Estuaries 22:636-647

Lenanton RCJ, Robertson AI, Hansen JA (1982) Nearshore accumulations of detached macrophytes as nursery areas for fish. Mar Ecol Prog Ser 9:51-57

Leonard L, Dixon KL, Pilkey OH (1990) A comparison of beach renourishment on the US Atlantic, Pacific and Gulf coasts. J Coast Res (Spec Issue) 6:127-140

Lindeman KC, Snyder DB (1998) Nearshore hardbottom fishes of southeast Florida and effects of habitat burial caused by dredging. Fish Bull 97:508-525

McDermott JJ (1983) Food web in the surf zone of an exposed sandy beach along the mid-Atlantic coast of the United States. In: McLachlan A, Erasmus T (eds) Sandy beaches as ecosystems. W Junk, The Hague, p 529-538 
McMichael RH Jr, Ross ST (1987) The relative abundance and feeding habits of juvenile kingfish (Sciaenidae: Menticirrhus) in a Gulf of Mexico surf zone. NE Gulf Sci 9:109-123

Modde T (1980) Growth and residency of juvenile fishes within a surf zone habitat in the Gulf of Mexico. Gulf Res Rep 6:377-385

Nelson WG (1993) Beach restoration in the southeastern US: environmental effects and biological monitoring. Ocean Coast Manage 19:157-182

Osenberg CW, Schmitt RJ, Holbrook SJ, Abu-Saba KE, Flegal AR (1994) Detection of environmental impacts: natural variability, effect size, and power analysis. Ecol Appl 4: $16-30$

Peterman RM (1990) Statistical power analysis can improve fisheries research and management. Can J Fish Aquat Sci 47:2-15

Peters DJ, Nelson WG (1987) The seasonality and spatial patterns of juvenile surf zone fishes of the Florida east coast. Florida Sci 50:85-99

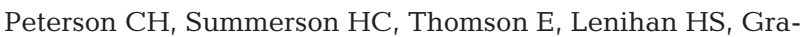
bowski J, Manning L, Micheli F, Johnson G (2000) Synthesis of linkages between benthic and fish communities as a key to protecting essential fish habitat. Bull Mar Sci 66:759-774

Pilkey OH, Wright HL III (1988) Seawalls versus beaches. J Coast Res (Spec Issue) 4:41-64

Pottern GB, Huish MT, Kerby JH (1989) Species profiles: life histories and environmental requirements of coastal fishes and invertebrates (mid-Atlantic) - bluefish. US Fish and Wildlife Service Biological Report 82(11.94). US Army Corps Engineers, TR EL-82-4. Vicksburg, MS, p 20

Reilly FJ, Bellis BJ (1983) The ecological impact of beach nourishment with dredged materials on the intertidal zone at Bogue Banks, North Carolina. Miscellaneous Report 83-3. US Army Engineer Coastal Engineering Research Center, Fort Belvoir, VA

Ross ST, McMichael RH Jr, Ruple DL (1987) Seasonal and diel variation in the standing crop of fishes and macroinverte-

Editorial responsibility: Kenneth Sherman (Contributing Editor), Narragansett, Rhode Island, USA brates from a Gulf of Mexico surf zone. Estuar Coast Shelf Sci 25:391-412

Ross SW, Lancaster JE (2002) Movements and site fidelity of two juvenile fish species using surf zone nursery habitats along the southeastern North Carolina coast. Env Biol Fish 63:161-172

Rotenberry JT, Wiens JA (1985) Statistical power analysis and community-wide patterns. Am Nat 125:164-168

Ruple D (1984) Occurrence of larval fishes in the surf zone of a northern Gulf of Mexico barrier island. Estuar Coast Shelf Sci 18:191-208

Schaefer RH (1967) Species composition, size and seasonal abundance of fish in the surf waters of Long Island. NY Fish Game J 1:1-46

Sheridan PF (1979) Trophic resource utilization by three species of sciaenid fishes in a northwest Florida estuary. NE Gulf Sci 3:1-5

Thomas L, Juanes F (1996) The importance of statistical power analysis: an example from animal behaviour. Anim Behav 52:856-859

Underwood AJ (1992) Beyond BACI: the detection of environmental impacts on populations in the real, but variable, world. J Exp Mar Biol Ecol 161:145-178

Van Dolah RF, Martore RM, Lynch AE, Wendt PH, Levisen MV, Whitaker DJ, Anderson WD (1994) Environmental evaluation of the folly beach nourishment project. Final report. Prepared for US Army Corps of Engineers, Charleston, South Carolina. Marine Resources Division, South Carolina Department of Natural Resources, Charleston, NC

Wilber DH, Clarke DG (2001) Biological effects of suspended sediments: a review of suspended sediment impacts on fish and shellfish with relation to dredging activities in estuaries. North Am J Fish Manage 21:855-875

Wilber DH, Clarke DG, Burlas MH, Ruben H, Will WJ (2003) Spatial and temporal variability in surf zone fish assemblages on the northern coast of New Jersey. Estuar Coast Shelf Sci 56:291-304

Wilkinson L (1990) SYSTAT: the system for statistics. SYSTAT Inc. Evanston, IL

Submitted: April 30, 2002; Accepted: November 18, 2002 Proofs received from author(s): March 6, 2003 